\title{
Analisis Penerimaan Audit Software Bagi Auditor Eksternal Dengan Menggunakan Pendekatan Technology Acceptance Model (Tam)
}

\author{
Alvin ${ }^{1)}$ \\ alvin_vincentius@yahoo.co.id \\ Kurniawati $^{2)}$ \\ Kurniawati@bundamulia.ac.id \\ Universitas Bunda Mulia
}

\begin{abstract}
Technology Acceptance Model (TAM) is a model that is used to determine the level of personal acceptance or user towards technology. This study aims to analyze the effect on the acceptance's level of audit software for external auditors using the TAM model. The construct of the TAM model used in this study consisted of 4 (four) main constructs, namely: perceived usefulness, perceived ease of use, attitude toward using and acceptance of audit software. This research was conducted with online questionnaires distributed to all auditors working in the Public Accounting Firm DKI Jakarta. Data collection techniques used purposive sampling and resulted 91 (ninety-one) respondents as final sample. Hyphotesis testing was performed by using Structural Equation Modelling (SEM) with WarpPLS 3.0 program. The results of this study indicate that the perceived ease of use variable has a significant and positive effect on perceived usefulness variable, the perceived ease of use and perceived usefulness have a significant and positive effect on attitude toward using variable, the perceived usefulness and attitude toward using variables have a significant and positive effect on acceptance of audit software variable.
\end{abstract}

The conclusion of this research shows that the level of audit software acceptance is very high based on individual perceptions about the usefulness and ease of audit software. It shows that the auditors highly and positively acceptance toward technological developments in auditing area. Suggestion for further research is conducting research related to the development of new technology in auditing area which enters the implementation phase of the industrial revolution era 4.0.

Keywords: Technology Acceptance Model, Audit Software, revolution industry 4.0

\begin{abstract}
ABSTRAK
Technology Acceptance Model (TAM) merupakan suatu model yang digunakan untuk mengetahui tingkat penerimaan seseorang atau pemakai terhadap penggunaan teknologi. Penelitian ini bertujuan untuk menganalisis pengaruh terhadap tingkat penerimaan audit software bagi auditor eksternal dengan menggunakan model TAM. Adapun konstruk
\end{abstract}


model TAM yang digunakan dalam penelitian ini terdiri dari 4 (empat) konstruk utama, yaitu: perceived usefulness (persepsi kegunaan), perceived ease of use (persepsi kemudahan penggunaan), attitude toward using (sikap terhadap penggunaan) dan penerimaan audit software.

Penelitian ini dilakukan dengan menggunakan kuesioner online dan disebarkan kepada auditor di Kantor Akuntan Publik (KAP) wilayah DKI Jakarta. Teknik pengumpulan data menggunakan purposive sampling dan menghasilkan sampel akhir sebanyak 91 (sembilan puluh satu) responden. Hipotesis dalam penelitian ini menggunakan model analisis statistik persamaan struktural (SEM) dengan bantuan program WarpPLS 3.0. Hasil penelitian menunjukkan bahwa variabel persepsi kemudahan penggunaan berpengaruh signifikan dan positif terhadap variabel persepsi kegunaan, variabel persepsi kemudahan penggunaan dan persepsi kegunaan berpengaruh signifikan dan positif terhadap variabel sikap terhadap penggunaan dan variabel persepsi kegunaan dan sikap terhadap penggunaan berpengaruh signifikan dan positif terhadap variabel penerimaan audit software.

Dari hasil penelitian dapat disimpulkan bahwa tingkat penerimaan audit software adalah sangat tinggi yang didasari oleh persepsi individu tentang kegunaan dan kemudahan audit software. Hal ini juga menunjukkan bahwa auditor sangat menerima dengan positif terhadap perkembangan teknologi di bidang auditing. Saran untuk penelitian selanjutnya adalah melakukan penelitian terkait perkembangan teknologi baru dalam bidang auditing yang memasuki tahap implementasi era revolusi industri 4.0.

Kata Kunci : Technology Acceptance Model (TAM), Audit Software, revolusi industri 4.0

\section{Pendahuluan}

Saat ini dunia sudah memasuki era revolusi industri 4.0 yang erat kaitannya dengan kemajuan teknologi yang pesat yang mengubah cara hidup setiap orang dalam bekerja maupun berinteraksi. Revolusi industri akan membawa inovasi dan perubahan terhadap model bisnis yang lebih efisien dan efektif serta mempercepat peningkatan daya saing sektor industri nasional secara signifikan. Inovasi yang muncul di era revolusi industri 4.0 itu antara lain adalah penerapan Information Communication Technology (ICT) di sektor industri, yang memanfaatkan sistem online document approval untuk mengawasi penyelesaian pekerjaan. Teknologi membawa dampak terhadap penghematan dalam penggunaan waktu dan biaya sehingga produk yang dihasilkan lebih murah dan mampu bersaing di pasar domestik maupun global. 
Perkembangan teknologi dalam proses bisnis telah mempengaruhi cara bekerja dalam berbagai macam bidang, salah satunya adalah bidang auditing. Menurut Arens et al. (2015) auditing adalah proses pengumpulan dan evaluasi bukti tentang informasi untuk menentukan dan melaporkan derajat kesesuaian antara informasi dengan kriteria yang telah ditetapkan. Proses pengumpulan dan evaluasi membutuhkan bukti audit. Terdapat berbagai jenis bukti audit, diantaranya yaitu: data elektronik dan data lain tentang terkait transaksi, komunikasi tertulis dengan pihak luar, observasi oleh auditor, serta kesaksian lisan pihak yang diaudit.

Data elektronik merupakan salah satu jenis bukti audit. Pada saat ini banyak perusahaan di dunia maupun di Indonesia yang telah melakukan pencatatan sistem akuntansi menggunakan program akuntansi terkomputerisasi daripada melakukan secara manual. Meningkatnya penggunaan software akuntansi yang terkomputerisasi tentunya akan berdampak terhadap para auditor yang bekerja di Kantor Akuntan Publik (KAP). Auditor harus memahami bagaimana perusahaan menggunakan teknologi informasi untuk mencatat, memproses dan melaporkan transaksi dalam laporan keuangan dalam suatu sistem komputer. Selain itu juga dengan adanya teknologi diharapkan dapat meningkatkan kemampuan auditor dalam melakukan analisis. Penggunaan teknologi yang canggih bertujuan untuk mempermudah pekerjaan manusia karena mempunyai manfaat efektivitas dan efisiensi pekerjaan yang diharapkan memberikan keuntungan baik secara financial maupun non financial.

Teknologi dalam bidang audit merupakan seperangkat alat bantu berupa software komputer yang dapat memudahkan pekerjaan auditor dalam mengumpulkan dan mengevaluasi bukti audit. Dengan adanya software tersebut auditor dapat melaksanakan pekerjaan audit menjadi lebih cepat dan akurat serta dapat memahami proses bisnis klien dengan lebih baik lagi. Berbagai macam penggunaan teknologi komputer dalam teknik audit dikenal dengan istilah Teknik Audit Berbantuan Komputer-TABK (Computer Assisted Audit Techniques-CAATs). CAATs adalah alat dan teknik yang digunakan oleh auditor untuk mengekstrak dan menganalisis data (Braun dan Davis, 2003; dalam Bierstaker et al, 2013). Menurut Ashari (2018) teknik audit berbantuan komputer adalah pelaksanaan dan pengumpulan bukti audit dengan menggunakan software komputer. Beberapa contoh software komputer dalam audit antara lain: Audit Command Language (ACL) dan Interactive Data Extraction and Analysis 
(IDEA). CAATs diharapkan dapat meningkatkan efektivitas dan efisiensi audit (Zhao et al, 2003; dalam Bierstaker et al, 2013). CAATs memungkinkan auditor untuk melakukan tes terhadap keseluruhan populasi (AICPA, 2001; Curtis \& Payne, 2008; Singleton, 2011; dalam Bierstaker et al, 2013) atau dapat memilih sampel dari transaksi dengan kriteria khusus untuk mendapatkan bukti terkait efektivitas pengendalian (AICPA, 2006; PCAOB, 2010; dalam Bierstaker et al, 2013). Teknik audit berbantuan komputer tidak bermaksud untuk meniadakan prosedur audit lainnya, akan tetapi lebih bersifat melengkapi prosedur pengujian dalam audit (Ashari, 2018).

Namun demikian, penggunaan teknologi tidak selalu memberikan dampak positif, akan tetapi juga dapat memberikan dampak negatif. Dengan kata lain, teknologi memberikan manfaat terhadap pengguna tetapi juga dapat menimbulkan masalah terhadap penggunanya. Salah satu contohnya adalah tidak semua pengguna bisa menerima atau menyesuaikan diri dengan perkembangan teknologi yang terjadi. Penerapan teknologi dalam suatu organisasi akan berpengaruh pada seluruh kegiatan organisasi, terutama pada sumber daya manusia. Faktor pengguna sangat penting untuk diperhatikan dalam penerapan sistem baru, karena tingkat kesiapan pengguna untuk menerima sistem baru mempunyai pengaruh besar dalam menentukan berhasil tidaknya pengembangan/penerapan sistem tersebut (Kustono, 2000; dalam Tangke, 2004).

Mengingat pentingnya untuk mengetahui tingkat penerimaan seseorang atau pemakai sistem terhadap teknologi, terdapat beberapa model untuk melihat tingkat penerimaan teknologi salah satunya adalah model TAM (Technology Acceptance Model) yang dikembangkan oleh Davis (1989). Tujuan utama TAM adalah: memberikan penjelasan tentang penentuan penerimaan komputer secara umum, memberikan penjelasan tentang perilaku/sikap pengguna dalam suatu populasi (Davis et al, 1989). Model TAM yang diperkenalkan oleh Davis (1989) terdiri dari persepsi kegunaan (perceived usefulness), persepsi kemudahan penggunaan (perceived ease of use), sikap (attitude), minat perilaku (behavior intention), dan penggunaan sesungguhnya (actual use). Menurut Fatmawati (2015) TAM adalah salah satu jenis teori yang menggunakan pendekatan teori perilaku (behavioral theory). Pendekatan ini sudah banyak digunakan untuk mengkaji proses adopsi penerapan teknologi informasi. Model pendekatan apapun seharusnya tidak hanya memprediksi tetapi juga harusnya 
bisa menjelaskan, dengan model TAM maka dapat menjelaskan bagaimana penerapan teknik audit berbantuan komputer (TABK) dapat diterapkan pada pengguna.

\section{Identifikasi Masalah}

Kemajuan era industri 4.0 menuntut para pelaku bisnis untuk segera berubah mengikuti perkembangan teknologi yang sangat pesat, jika bisnis tersebut ingin tetap bertahan dan maju. Perkembangan teknologi dan model bisnis memberikan dampak yang signifikan terhadap para auditor. Hal ini menuntut auditor untuk memahami bagaimana model proses bisnis yang dijalankan oleh kliennya. Auditor juga harus melakukan kearifan profesional dalam perencanaan dan pelaksanaan audit laporan keuangan (Hayes et al, 2017).

Untuk membantu proses audit, maka muncul suatu teknologi yang dikenal dengan istilah Teknik Audit Berbantuan Komputer-TABK (Computer Assisted Audit Techniques-CAATs). CAATs adalah alat dan teknik yang digunakan oleh auditor untuk mengekstrak dan menganalisis data (Braun dan Davis, 2003; dalam Bierstaker et al, 2013). CAATs diharapkan dapat meningkatkan efektivitas dan efisiensi audit (Zhao et al, 2003; dalam Bierstaker et al, 2013). Meskipun dengan adanya tuntutan standar audit dan perkembangan teknologi yang pesat dengan segala manfaat dan kemudahan yang dapat dirasakan, Bierstaker et al. (2013) menyatakan bahwa tingkat penggunaan CAATs masih cukup rendah. Oleh karena itu penting sekali untuk mengetahui faktor-faktor apa saja yang mempengaruhi penerimaan audit software bagi auditor eksternal dengan menggunakan suatu model penerimaan teknologi. Dengan mengetahui faktor - faktor tersebut diharapkan dapat meningkatkan penggunaan CAATs di masa mendatang.

\section{Tinjauan Literatur}

\section{Peranan Audit \& Tahapan - Tahapan dalam Proses Audit}

Menurut Arens et al. (2015) auditing adalah pengumpulan dan evaluasi bukti tentang informasi untuk menentukan dan melaporkan derajat kesesuaian antara informasi dan kriteria yang telah ditetapkan. Auditing harus dilakukan oleh orang yang kompeten, independen, integritas dan objektif. Selain itu auditor diwajibkan untuk mematuhi persyaratan etika yang dianggap relevan, termasuk terkait dengan independensi. Dalam kaitannya dengan penugasan audit laporan keuangan, auditor 
harus merencanakan dan melaksanakan audit dengan kewaspadaan profesional (professional skepticism), mengingat bahwa adanya kemungkinan salah saji material dalam laporan keuangan. Auditor juga harus melakukan kearifan profesional dalam perencanaan dan pelaksanaan audit laporan keuangan (ISA 200; dalam Hayes et al, 2017). Menurut Hayes et al. (2017) terdapat beberapa tahapan dalam proses audit yaitu (1) tahap penerimaan klien (2) tahap perencanaan (3) tahap pengujian dan bukti (4) tahap evaluasi dan pelaporan.

\section{Teknik Audit Berbantuan Komputer (TABK) Dalam Proses Audit}

Menurut Ashari (2018) teknik audit berbantuan komputer adalah pelaksanaan dan pengumpulan bukti audit dengan menggunakan software komputer baik software paket maupun software umum. Adapun contoh dari software audit antara lain adalah Audit Command Language (ACL) dan Interactive Data Extraction and Analysis (IDEA).

Keberadaan teknik audit berbantuan komputer tidak dimaksudkan untuk meniadakan atau menghilangkan prosedur audit lain tetapi bersifat melengkapi prosedur pengujian dalam audit. Menurut Hayes et al. (2017) penggunaan CAATs memungkinkan adanya pengujian yang lebih ekstensif atas sejumlah transaksi elektronik dan catatan akuntansi. CAATs juga dapat digunakan untuk memilih sampel transaksi dari catatan elektronik yang utama untuk mengelompokkan transaksi tersebut ke dalam kriteria tertentu, atau menguji seluruh populasi daripada sampel.

\section{Faktor-Faktor Yang Mempengaruhi Penerimaan Audit Software dengan Model TAM}

Technology Acceptance Model (TAM) dikembangkan oleh Davis (1989) berdasarkan model dari theory of reasoned action (TRA). Model asli TAM terdiri dari persepsi kegunaan (perceived usefulness), persepsi kemudahan penggunaan (perceived ease of use), sikap (attitude), minat perilaku (behavior intention), dan penggunaan sesungguhnya (actual use). Technology Acceptance Model (TAM) dikembangkan dengan mengkhususkan pada bidang sistem informasi untuk memprediksi penerimaan dan penggunaan sistem informasi pada pekerjaan individual pemakai. Dalam Technology Acceptance Model (TAM) terdapat dua konstruk utama yaitu persepsi 
kegunaan (perceived usefulness) dan persepsi kemudahan penggunaan (perceived ease of use). Setelah dikembangkan oleh Davis (1989), model TAM banyak digunakan dan dikembangkan oleh peneliti lainnya, salah satunya adalah penelitian yang dilakukan Tangke (2004) menggunakan model TAM yang sudah dimodifikasi oleh Gahtani (2001) Berikut ini adalah gambar paradigma penelitian yang mengacu pada model TAM yang digunakan oleh Tangke (2004) :

\section{Gambar 2.2}

\section{Paradigma Penelitian}

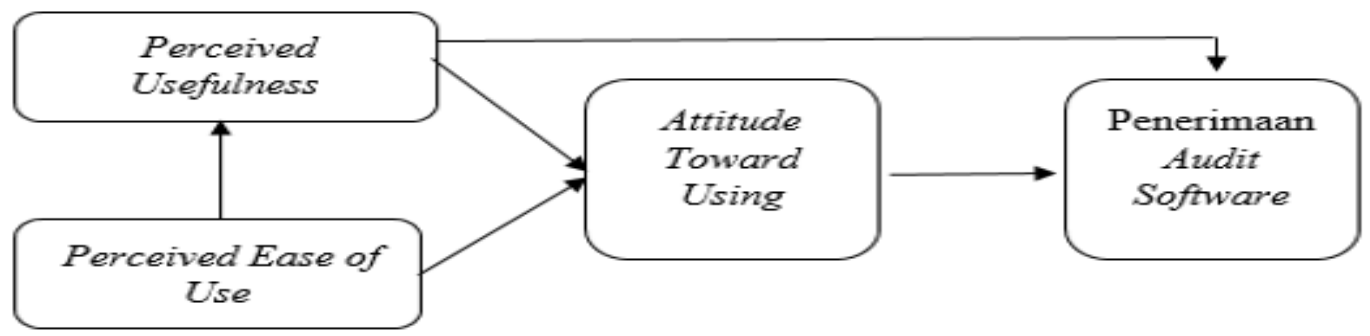

Sumber: Modifikasi Model TAM, Tangke (2004)

\section{Hipotesis Penelitian}

Pengaruh Perceived Ease of Use terhadap Perceived Usefulness

Menurut Davis (1989) perceived ease of use didefinisikan sebagai suatu tingkat atau keadaan dimana seseorang yakin bahwa dengan menggunakan sistem tertentu tidak diperlukan usaha apapun atau free of effort. Dalam penelitian Davis et al. (1989) perceived usefulness memiliki dampak langsung terhadap penerimaan teknologi tetapi juga dampak tidak langsung yang disebabkan adanya pengaruh dari perceived ease of use terhadap perceived usefulness. Menurut penelitian Nugraha dan Laksito (2014) perceived ease of use berpengaruh positif terhadap perceived usefulness. Berdasarkan hal tersebut, maka hipotesis pertama dalam penelitian ini adalah sebagai berikut:

\section{$\mathrm{H}_{1} \quad$ : Perceived Ease of Use berpengaruh signifikan positif terhadap Perceived Usefulness}

\section{Pengaruh Perceived Usefulness terhadap Attitude toward Using}

Menurut Santoso (2012) perceived usefulness didefinisikan sebagai sejauh mana seseorang meyakini bahwa penggunaan sistem informasi tertentu akan meningkatkan 
kinerjanya. Dari definisi tersebut dapat dikatakan bahwa kegunaan persepsian merupakan suatu kepercayaan tentang proses pengambilan keputusan. Jika seseorang merasa percaya bahwa sistem tersebut berguna maka dia akan menggunakannya tetapi sebaliknya jika seseorang merasa percaya bahwa sistem informasi tidak atau kurang berguna maka dia tidak akan menggunakannya. Maka hal ini akan menyebabkan adanya tindakan penerimaan atau penolakan dari pengguna. Hasil penelitian Santoso (2012) menunjukkan bahwa perceived usefulness berpengaruh positif terhadap attitude toward using. Berdasarkan hal tersebut, maka hipotesis kedua dalam penelitian ini adalah sebagai berikut:

\section{$\mathrm{H}_{2}$ : Perceived Usefulness berpengaruh signifikan positif terhadap Attitude toward Using}

\section{Pengaruh Perceived Ease of Use terhadap Attitude toward Using}

Menurut Davis (1989) perceived ease of use didefinisikan sebagai suatu tingkat atau keadaan dimana seseorang yakin bahwa dengan menggunakan sistem tertentu tidak diperlukan usaha apapun atau free of effort. Dalam penelitian Davis et al. (1989) perceived ease of use merupakan faktor penentu kedua dalam menentukan minat seseorang menggunakan teknologi. Menurut Santoso (2012) meskipun usaha menurut setiap orang bebeda-beda tetapi pada umumnya untuk menghindari penolakan dari pengguna sistem atas sistem yang dikembangkan, maka sistem harus mudah diaplikasikan oleh pengguna tanpa mengeluarkan usaha yang dianggap memberatkan. Hasil penelitian Kulviwat et al. (2007) menunjukkan bahwa perceived ease of use berpengaruh positif terhadap attitude toward using. Berdasarkan hal tersebut, maka hipotesis ketiga dalam penelitian ini adalah sebagai berikut:

\section{$\mathrm{H}_{3}$ : Perceived Ease of Use berpengaruh signifikan positif terhadap Attitude toward Using}

\section{Pengaruh Attitude toward Using terhadap Penerimaan Audit Software}

Menurut Fatmawati (2015) attitude toward using merupakan sikap pengguna terhadap penggunaan sistem informasi yang berbentuk penerimaan ataupun penolakan. Menurut Budiman, 2013; dalam Armanda, 2015, seseorang akan menerima penggunaan sistem informasi atau teknologi jika dia merasa senang, merasakan manfaat dan fitur fiturnya yang tidak membosankan. Menurut Nugraha dan Laksito (2014) attitude 
toward using merupakan perilaku untuk menggunakan sistem informasi, semakin tinggi keinginan seseorang untuk menggunakan sebuah sistem informasi, maka akan semakin sering intensi untuk menggunakannya. Hasil penelitian Tangke (2004) menunjukkan bahwa attitude toward using berpengaruh terhadap penerimaan TABK. Berdasarkan hal tersebut, maka hipotesis keempat dalam penelitian ini adalah sebagai berikut:

\section{$\mathrm{H}_{4}$ : Attitude toward Using berpengaruh signifikan positif terhadap Penerimaan}

\section{Audit Software.}

\section{Pengaruh Perceived Usefulness terhadap Penerimaan Audit Software}

Menurut Fatmawati (2015) penerimaan (acceptance) ini sebenarnya meliputi variabel intensitas perilaku penggunaan sistem informasi dan penggunaan sistem informasi secara aktual sehingga salah satu indikator yang digunakan adalah system usage. Menurut Nugraha dan Laksito (2014) penggunaan sistem teknologi dapat memberikan manfaat bagi para pengguna, yaitu dapat memperoleh informasi yang relevan, akurat, tepat waktu, dan lengkap yang diperlukan serta meningkatkan produktivitas kinerja. Penggunaan sesungguhnya dari teknologi akan mampu diterima oleh seseorang bila dirasakan kebermanfaatannya. Hasil penelitian Mulyani dan Kurniadi (2015) yang menyatakan bahwa perceived usefulness berpengaruh terhadap minat untuk menerima dan menggunakan teknologi. Berdasarkan hal tersebut, maka hipotesis kelima dalam penelitian ini adalah sebagai berikut:

H5 : Perceived Usefulness berpengaruh signifikan positif terhadap Penerimaan Audit Software.

\section{Metode Penelitian}

\section{Populasi \& Sampel}

Populasi dalam penelitian ini adalah seluruh auditor yang menggunakan audit software pada Kantor Akuntan Publik di DKI Jakarta. Pengambilan sampel pada penelitian ini dilakukan dengan teknik purposive sampling. Adapun kriteria dalam penentuan sampel ini adalah auditor eksternal yang saat ini sedang bekerja atau pernah memiliki pengalaman bekerja pada KAP di DKI Jakarta serta pernah menggunakan audit software yang khusus dibuat untuk KAP atau menggunakan audit software umum 
yang dibuat oleh perusahaan pembuat audit software. Sampel akhir yang memenuhi kriteria adalah sebanyak 91 responden.

\section{Jenis Penelitian}

Jenis penelitian ini termasuk dalam jenis penelitian yang menggunakan metode survei. Menurut Priyono (2016) penelitian metode survei merupakan penelitian yang menggunakan kuesioner sebagai instrumen penelitian. Penelitian ini mengacu pada penelitian Armanda (2015); Santoso (2012); Darmaningtyas dan Suardana (2017); Nugraha dan Laksito (2014); Tangke (2004); Suryandini (2010); Rahayu et al. (2017) yang melakukan penelitian mengenai penerimaan seseorang terhadap teknologi informasi dengan metode survei dan menggunakan kuesioner.

\section{Operasionalisasi Variabel}

1. Variabel Eksogen (Independen)

a. Perceived Usefulness (PU)

Perceived Usefulness atau kegunaan yang dirasakan didefinisikan sebagai suatu tingkat atau keadaan dimana seseorang yakin bahwa dengan menggunakan sistem tertentu akan meningkatkan kinerjanya (Davis, 1989; dalam Tangke, 2004). Menurut Fatmawati (2015), beberapa indikator terkait persepsi kegunaaan antara lain: mempercepat pekerjaan, meningkatkan produktifitas kerja, meningkatkan kinerja, meningkatkan efektifitas tugas, adanya kebermanfaatan secara keseluruhan, mempermudah pekerjaan, adanya penilaian bahwa sistem informasi yang digunakan bermanfaat bagi pengguna.

b. Perceived Ease of Use (PE)

Perceived Ease of Use didefinisikan sebagai suatu tingkat atau keadaan dimana seseorang yakin bahwa dengan menggunakan sistem tertentu tidak diperlukan usaha apapun atau free of effort (Davis, 1989; dalam Tangke, 2004). Menurut Fatmawati (2015) merupakan pernyataan mengenai persepsi pengguna akan kemudahan ataupun kesulitan dari penggunaan sistem informasi. Indikatornya, antara lain: mudah untuk dipelajari, dapat dikendalikan, jelas dan dapat dipahami, sistem informasi yang fleksibel, mudah digunakan, mahir bagi pengguna, adanya penilaian bahwa secara umum sistem informasi tersebut mudah digunakan.

c. $\quad$ Attitude Toward Using (ATT) 
Menurut Fatmawati (2015) sikap terhadap penggunaan atau attitude toward using merupakan sikap pengguna terhadap penggunaan sistem informasi yang berbentuk penerimaan ataupun penolakan. Jadi dalam konteks sikap ini, pengguna akan menunjukkan sikapnya apakah dia menerima ataupun menolak terhadap sistem informasi tersebut.

2. Variabel Endogen (Dependen) - Acceptance Audit Software (ACC)

Dalam penelitian ini terdapat variabel endogen yaitu penerimaan terhadap Software Audit (ACC).Menurut Fatmawati (2015) penerimaan (acceptance) ini sebenarnya meliputi variabel intensitas perilaku penggunaan sistem informasi dan penggunaan sistem informasi secara aktual. Untuk mengetahui bagaimana teknologi benar-benar diterima oleh pengguna, maka dapat dilihat dari indikator intensitas pengguna dalam menggunakan, mengakses sistem sampai tercipta kepuasan penggunanya.

\section{Metode Analisis Data}

Metode analisis data yang digunakan dalam penelitian ini dengan menggunakan SEM (Structural Equation Model) atau model persamaan struktural. Menurut Sugiyono (2015), SEM dapat dideskripsikan sebagai suatu analisis yang menggabungkan pendekatan analisis faktor (factor analysis), model struktural (structural model), dan analisis jalur (path analysis). Dalam model analisis SEM dapat dilakukan tiga macam kegiatan secara serentak, yaitu pengujian validitas dan reliabilitas instrumen, pengujian model hubungan antar variabel, dan kegiatan untuk mendapatkan suatu model yang cocok untuk prediksi. Menurut Sholihin \& Ratmono (2013) model struktural pada WarpPLS terdiri dari yaitu (1) Model Pengukuran (Outer Model) dan (2) Model Struktural (Inner Model). Software yang dipakai untuk analisis SEM dalam penelitian ini adalah WarpPLS versi 3.0. Penelitian ini menggunakan skala Likert dengan interval $1-4$.

\section{Hasil dan Pembahasan}

\section{Deskripsi Objek Penelitian}

Data dalam penelitian ini menggunakan data primer yang diperoleh melalui kuisioner yang disebarkan secara online dengan menggunakan Google Drive yang disebarkan 
kepada auditor eksternal yang bekerja di KAP wilayah DKI Jakarta. Total responden yang mengisi kuesioner dalam periode waktu penyebaran kuesioner berjumlah 95 orang, namun pada akhirnya terpilihlah 91 orang yang memenuhi kriteria yang telah ditetapkan. Dari 91 responden yang mengisi kuisioner tersebut masih didominasi oleh auditor eksternal perempuan yaitu 52,75\% sedangkan auditor ekternal laki - laki adalah $47,25 \%$. Adapun responden yang mengisi kuisioner ini berasal dari berbagai level fungsional yaitu Junior Auditor (58,24\%), Senior Auditor (37,36\%), Manager (2,2\%) dan Partner (2,2\%). Selain itu dari data juga menunjukkan bahwa dari 91 responden, $75,82 \%$ adalah responden yang bekerja di KAP Big 4, sedangkan, 24,18\% dari responden di KAP Non Big 4. Adapun audit software yang digunakan oleh para responden di KAP tempat mereka bekerja antara lain adalah ACL, IDEA, Personnel Audit Software, Engagement Management System (EMS), EY Helix EY Canvas, EY Random, dan $\mathrm{CCH}$

\section{Hasil \& Pembahasan}

Setelah dinyatakan lolos dari serangkaian pengujian baik outer model maupun inner model, maka berikut ini output pengujian dengan menggunakan WarpPLS 3.0 dengan tingkat signifikansi 5\%:

\section{Gambar 4.1}

$\mathbf{u}$

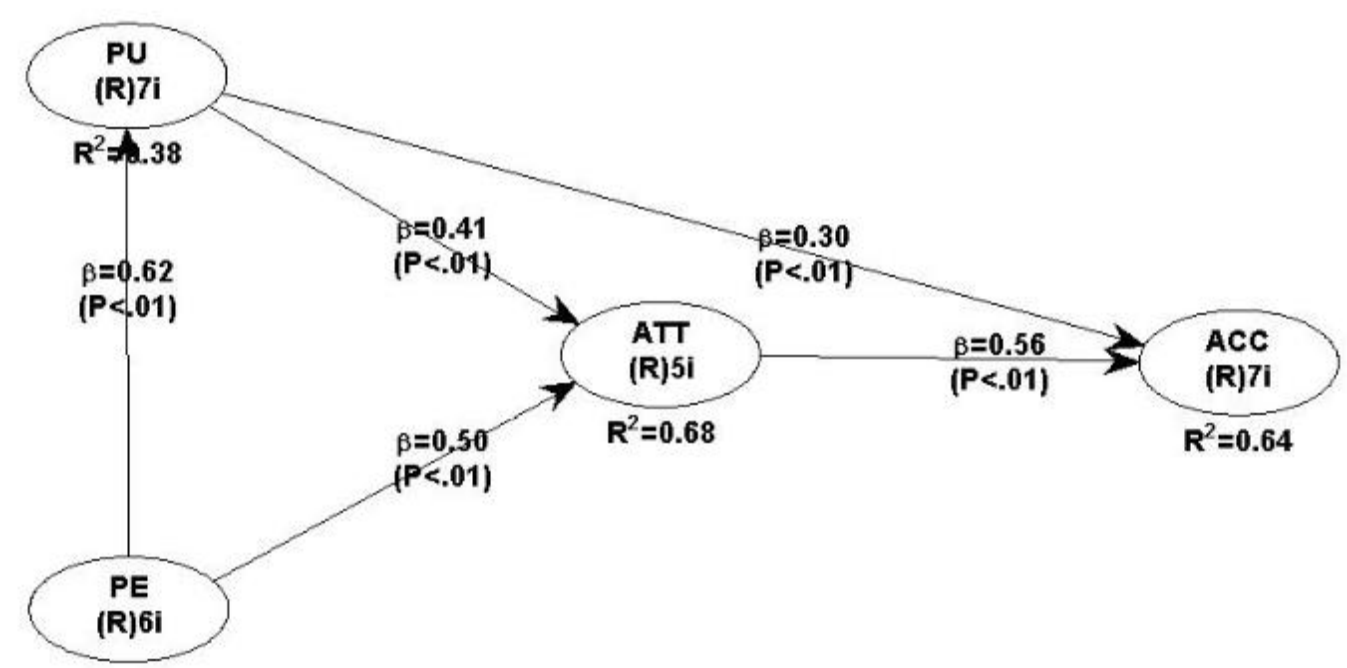


Sumber: Hasil Olahan Data Peneliti Dengan WarpPLS 3.0 (2018)

\section{Hasil Uji Hipotesis:}

\section{Pengaruh Perceived Ease of Use terhadap Perceived Usefulness}

Berdasarkan hasil pengolahan data, menunjukkan bahwa nilai $p$-value pada perceived ease of use terhadap perceived usefulness adalah $<0.01$, yang menunjukkan nilai $p$ value lebih kecil dari 0.05. Maka dengan hasil tersebut, $\mathrm{H}_{1}$ diterima dan $\mathrm{H}_{0}$ ditolak dengan nilai koefisien jalur sebesar 0.62. Dengan hasil tersebut, dapat dikatakan bahwa perceived ease of use berpengaruh signifikan positif terhadap perceived usefulness. Hasil penelitian ini sejalan dengan penelitian yang dilakukan oleh Armanda (2015).

\section{Pengaruh Perceived Usefulness terhadap Attitude Toward Using}

Berdasarkan hasil pengolahan data, menunjukkan bahwa nilai $p$-value pada perceived usefulness terhadap attitude toward using adalah $<0.01$, yang menunjukkan nilai $p$ value lebih kecil dari 0.05. Maka dengan hasil tersebut, $\mathrm{H}_{2}$ diterima dan $\mathrm{H}_{0}$ ditolak dengan nilai koefisien jalur sebesar 0.41. Dengan hasil tersebut, dapat dikatakan bahwa perceived usefulness berpengaruh signifikan positif terhadap attitude toward using. Hasil penelitian ini sejalan dengan penelitian yang dilakukan oleh Mulyani dan Kurniadi (2015) yang menyatakan bahwa perceived usefulness berpengaruh positif terhadap attitude toward using.

\section{Pengaruh Perceived Ease of Use terhadap Attitude toward Using}

Berdasarkan hasil pengolahan data, menunjukkan bahwa nilai $p$-value pada perceived ease of use terhadap attitude toward using adalah $<0.01$, yang menunjukkan nilai $p$ value lebih kecil dari 0.05. Maka dengan hasil tersebut, $\mathrm{H}_{3}$ diterima dan $\mathrm{H}_{0}$ ditolak dengan nilai koefisien jalur sebesar 0.50. Dengan hasil tersebut, dapat dikatakan bahwa perceived ease of use berpengaruh signifikan positif terhadap attitude toward using. Hasil penelitian ini sejalan dengan penelitian yang dilakukan oleh Wida et al. (2016) yang menyatakan bahwa perceived ease of use berpengaruh signifikan positif terhadap attitude toward using.

\section{Pengaruh Attitude toward Using terhadap Penerimaan Audit Software}

Berdasarkan hasil pengolahan data, menunjukkan bahwa nilai $p$-value pada attitude toward using terhadap penerimaan audit software adalah $<0.01$, yang menunjukkan nilai p-value lebih kecil dari 0.05. Maka dengan hasil tersebut, $\mathrm{H}_{4}$ diterima dan $\mathrm{H}_{0}$ 
ditolak dengan nilai koefisien jalur sebesar 0.56. Dengan hasil tersebut, dapat dikatakan bahwa attitude toward using berpengaruh signifikan positif terhadap penerimaan audit software. Hasil penelitian ini sejalan dengan penelitian yang dilakukan oleh Gahtani (2001) yang menyatakan bahwa attitude toward using berpengaruh positif terhadap penerimaan audit software.

\section{Pengaruh Perceived Usefulness terhadap Penerimaan Audit Software}

Berdasarkan hasil pengolahan data, menunjukkan bahwa nilai $p$-value pada perceived usefulness terhadap penerimaan audit software adalah $<0.01$, yang menunjukkan nilai p-value lebih kecil dari 0.05. Maka dengan hasil tersebut, $\mathrm{H}_{5}$ diterima dan $\mathrm{H}_{0}$ ditolak dengan nilai koefisien jalur sebesar 0.30. Dengan hasil tersebut, dapat dikatakan bahwa perceived usefulness berpengaruh signifikan positif terhadap penerimaan audit software. Hasil penelitian ini sejalan dengan penelitian yang dilakukan oleh Santoso (2012) yang menyatakan bahwa perceived usefulness berpengaruh positif terhadap penerimaan audit software.

\section{Kesimpulan, Keterbatasan dan Saran}

Berdasarkan analisis dan pembahasan pada bagian sebelumnya, maka dapat ditarik kesimpulan sebagai berikut:

1. Perceived ease of use memiliki pengaruh signifikan positif terhadap perceived usefulness. Hasil ini menunjukkan bahwa kemudahan penggunaan audit software dapat mengurangi usaha atau effort yang diperlukan oleh auditor, baik waktu maupun tenaga yang diperlukan oleh auditor menjadi lebih sedikit dengan adanya audit software. Audit software memberikan kemudahan dan kegunaan dalam proses pengumpulan dan pengolahan bukti audit. Cakupan informasi yang dapat dikumpulkan juga menjadi lebih luas. Hal itu dapat membantu auditor untuk mendeteksi kesalahan maupun kecurangan yang ada dalam laporan keuangan. Dampak tersebut memberikan pengaruh terhadap pekerjaan audit yang dilakukan, audit software tidak hanya memberikan manfaat dan kemudahan untuk penggunanya saja, tetapi juga terhadap pekerjaan yang dilakukan dan hasil dari pekerjaan tersebut.

2. Perceived usefulness memiliki pengaruh signifikan positif terhadap attitude toward using. Hasil ini menunjukkan bahwa adanya manfaat yang diberikan oleh audit 
software, dapat memberikan dampak yang secara langsung dirasakan oleh pengguna. Hal itu akan memberikan pengaruh terhadap sikap yang ditunjukkan. Pengguna akan merasa lebih senang dengan pekerjaannya dan menerima audit software tersebut.

3. Perceived ease of use memiliki pengaruh signifikan positif terhadap attitude toward using. Hasil ini menunjukkan bahwa adanya kemudahan yang diberikan oleh audit software, dapat memberikan dampak yang secara langsung dirasakan oleh pengguna. Hal itu akan memberikan pengaruh terhadap sikap yang ditunjukkan. Pengguna akan merasa lebih senang dengan pekerjaannya dan menerima audit software tersebut.

4. Attitude toward Using memiliki pengaruh signifikan positif terhadap penerimaan audit software. Hasil ini menunjukkan bahwa sebagian besar pengguna menunjukkan perasaan senang dengan adanya audit software dan merasa puas dengan hasil pekerjaan yang dihasilkan. Hal tersebut mencerminkan bagaimana tingkat penerimaan pengguna terhadap audit software.

5. Perceived usefulness memiliki pengaruh signifikan positif terhadap penerimaan audit software. Hasil ini menunjukkan bahwa adanya manfaat yang diberikan oleh audit software, dapat memberikan dampak yang secara langsung mempengaruhi penggunaan nyata. Hal tersebut akan meningkatkan intensitas penggunaan audit software dan tingkat kepuasannya.

Adapun keterbatasan dalam penelitian ini adalah sebagai berikut:

1. Penelitian ini hanya mewakili persepsi dari auditor eksternal di wilayah DKI Jakarta saja.

2. Data penelitian ini bersifat subjektif yaitu berdasarkan persepsi responden melalui kuesioner. Tidak menutup kemungkinan bahwa persepsi responden berbeda dengan keadaan yang sesungguhnya

3. Ada beberapa variabel eksternal lainnya yang belum dikembangkan dalam penelitian ini.

Berdasarkan keterbatasan di atas maka saran - saran yang diajukan adalah sebagai berikut:

1. Penelitian selanjutnya diharapkan dapat memperluas area survey penelitian dengan responden yang tersebar di beberapa wilayah Indonesia. 
2. Penelitian selanjutnya diharapkan dapat menambahkan variabel eksternal dalam konstuk yang digunakan untuk penelitian, salah satu contohnya adalah karakteristik pengguna.

3. Penelitian selanjutnya diharapkan dapat menambahkan lebih banyak responden yang digunakan dalam penelitian terhadap penerimaan audit software.

4. Penelitian selanjutnya diharapkan dapat menambahkan atau menggabungkan teknik pengumpulan data dengan wawancara.

\section{DAFTAR REFERENSI}

Arens, A. A., Elder, R. J., \& Beasley, M. S. (2015). Auditing \& Jasa Assurance: Pendekatan Terintegrasi (Adaptasi Indonesia) Edisi 15 Jilid 1. Jakarta: Erlangga.

Armanda, R. (2015). Analisis Faktor Penerimaan dan Penggunaan Teknologi Dalam Sistem Informasi Akuntansi Dengan Pendekatan TAM. Jurnal Ilmu \& Riset Akuntansi Vol. 4 No. 3.

Ashari. (2018). Teknik Audit Berbantuan Komputer Dengan Ms. Excel, ACL dan IDEA. Jakarta: Elex Media Komputindo.

Bierstaker, J., Janvrin, D., \& Lowe, D. J. (2013). What Factors Influence Auditors' use of Computer-Assisted Audit Techniques. Advances in Accounting, Incorporating Advances in International Accounting.

Darmaningtyas, I. G., \& Suardana, K. A. (2017). Pengaruh Technology Acceptance Model (TAM) dalam Penggunaan Software Oleh Auditor yang Berimplikasi pada Kinerja Auditor. E-Jurnal Akuntansi Universitas Udayana Vol 21.3 ISSN: 2302-8556.

Davis, F. D., Bagozzi, R. P., \& Warshaw, P. R. (1989). User Acceptance of Computer Technology: A Comparison of Two Theoritical Model. Management Science Vol. 35 No. 8.

Davis, F. D. (1989). Perceived Usefulness, Perceived Ease of Use and User Acceptance of Computer Technology. MIS Quertely Vol. 13 No. 3.

Fatmawati, E. (2015). Technology Acceptance Model (TAM) Untuk Menganalisis Penerimaan Terhadap Sistem Informasi Perpustakaan. Jurnal Iqra' Volume 09 No. 01 .

Gahtani, S. S. (2001). The Applicability of TAM Outside North America: An Empirical Test in the United Kingdom. Information Resources Management Journal Vol. 14 No. 3.

Hayes, R., Wallage, P., \& Gortemaker, H. (2017). Prinsip-Prinsip Pengauditan Edisi Ketiga. Jakarta: Salemba Empat. 
Kulviwat, S., Bruner, G. C., Kumar, A., Nasco, S. A., \& Clark, T. (2007). Toward a Unified Theory of Comsumer Acceptance Technology. Psychology \& Marketing Vol. 24 No. 12.

Mulyani, A., \& Kurniadi, D. (2015). Analisis Penerimaan Teknologi Student Information Terminal (S-IT) Dengan Menggunakan Technology Acceptance Model (TAM) . Jurnal Ilmiah Manajemen dan Teknik Informatika Vol. 7 No.12 ISSN: $1978-8444$.

Nugraha, A., \& Laksito, H. (2014). Anteseden Penerimaan Teknologi Informasi Dalam Profesi Audit Internal Dengan Menggunakan Technology Acceptance Model. Diponegoro Journal of Accounting Volume 3 Nomor 2 ISSN: 2337-3806.

Priyono. (2016). Metode Penelitian Kuantitatif. Surabaya: Zifatama.

Santoso, B. (2012). Pengaruh Perceived Usefulness, Perceived Ease of Use, dan Perceived Enjoymend terhadap Penerimaan Teknologi Informasi. Surakarta: Universitas Sebelas Maret.

Sugiyono. (2015). Statistika Untuk Penelitian. Bandung: Alfabeta.

Sholihin, M., \& Ratmono, D. (2013). Analisis SEM-PLS dengan WarpPLS 3.0. Yogyakarta: Andi.

Suryandini, D. (2010). Aplikasi Model Penerimaan Teknologi Dalam Penggunaan Software Audit oleh Auditor. Jurnal Dinamika Akuntansi Vol. 2 No. ISSN: 2085-4277 Universitas Negeri Semarang.

Rahayu et al. (2017). Analisis Penerimaan E-Learning Menggunakan Technology Acceptance Model (Studi Kasus: Universitas Atma Jaya Yogyakarta). JUTEI Edisi Volume 1 No. 2 ISSN: 2579-3675 E-ISSN: 2579-5538 Universitas Atma Jaya Yogyakarta.

Tangke, N. (2004). Analisa Penerimaan Penerapan Teknik Audit Berbantuan Komputer (TABK) dengan Menggunakan Technology Acceptance Model (TAM) pada Badan Pemeriksa Keuangan (BPK) RI. Jurnal Akuntansi dan Keuangan Vol. 6 No. 1 Universitas Kristen Petra.

Wida, P. A., Yasa, N. N., \& Sukaatmadja, I. P. (2016). Aplikasi Model TAM (Technology Acceptance Model) Pada Perilaku Pengguna Instagram. Jurnal Ilmu Manajemen Vol. 6 No. 2 Universitas Udayana. 